$83 \%$ D0\%BC\%D0\%B5\%D0\%BD\%D1\%82\%D1\%8B/Downloads/pravovaya_sreda_ venchurnoy_deyatelnosti.pdf] (accessed 27 January 2016).

17. PWC MoneyTree [Electronic resource]: report. Available at: https://www.pwcmoneytree.com.

18. Rasporjazhenie Pravitelstva Rossiiskoy Federatsii ot 08.12. 2011 № 2227-r «Ob utverzhdenii Strategii innovacionnogo razvitija Rossijskoj Federacii na period do 2020 goda» [The disposal of the P. R. F. from 08.12. 2011 № 2227-R “On approval of strategy of innovative development of the Russian Federation for the period till 2020]. Sobranie zakonodatel'stva RF, no. 1.

19. Ugnich E.A., Boguslacskij I.V. (2014) Razvitie venchurnoj jecosistemy: rol' organizacionnoj kultury [The development of the VC ecosystem: the role of organizational culture]. Internetzhurnal Naukovedenie, vol.2, no. 21.

20. Venchurnye rynki [Jelektronnyj resurs]: doklad RVK i EY. [Venture markets [Electronic resource]: report of RVC and EY]. Available at: http://www.rusventure.ru/ru/programm/ analytics/docs/201402_RVC_EY_venture_markets_RU.pdf (accessed 25 January 2016).

21. Venchurnyj rynok v Rossii [Jelektronnyj resurs]: doklad FRII. [Venture market in Russia [Electronic resource]: report of IIDF]. Available at: http://www.iidf.ru/upload/frii/IIDF_ StartTrack_report2015.pdf (accessed 20 January 2016).

22. Wonglimpiyarat J. (2016) Exploring strategic venture capital financing with Silicon Valley style. Technological Forecasting and Social Change, vol. 102, pp. 80-89.

23. Zhao X., Hwang B.G., Yu G.S. (2013) Identifying the critical risks in underground rail international construction joint ventures: case study of Singapore. International Journal of Project Management, vol. 31, no. 4, pp. 554-566.

\title{
EXCHANGE TRADED FUNDS (ETF)ㄹ: HISTORY, MECHANISM, ACADEMIC LITERATURE REVIEW AND RESEARCH PERSPECTIVES ${ }^{2}$
}

\author{
Evgeni B. Tarassov, \\ Phd candidate National Research University Higher School of Economics, \\ Department of Finance, Russia, 101100, Moscow, Myasnitskaya str. 20; \\ Head of Wealth Management Institute, Moscow, E-mail: etarassovet@gmail.com
}

\begin{abstract}
Prior to March of 2016, when the first exchange traded fund (ETF) on RTS was introduced, Russian investors' only option for investing in the domestic index was through a mutual fund. By contrast, the majority world stock exchanges have been giving their clients the option to invest in their leading domestic indexes not only via index mutual funds but also via exchange traded funds (ETF) since decades. Their absence and therefore the lake of familiarity with these funds might be one of the several reasons Russian investors have been willing to pay a premium for ETF investments through intermediaries relative to what they would pay investing directly. Large number of investors buy western ETF via mutual funds. The premiums Russian mutual funds charge for investing in ETFs translate on up to a $36 \%$ premium over a 10-year horizon, compared to buying the same ETF directly. This paper introduces to a broader Russian speaking community ETFs, one of the most important financial innovations of the last 20 years, and provides a survey of the research done in this field. This paper reviews the literature on ETFs and provides a brief history of ETFs and these funds' investment mechanism. In conclusion, some ideas for further research are suggested.

\footnotetext{
${ }^{1}$ ETF (Exchange-Traded Funds). The main difference from mutual funds: shares of an ETF are traded on a stock exchange like equity of any other listed company. Mutual fund units might be bought or sold only once per day.

${ }^{2}$ The author is very grateful to Anton Suvorov (HSE), my supervisor, who spent many hours in conversation, for his very valuable advice. Sergei Stepanov (HSE), Alexei Goriaev (NES) and Andrei Simonov (Michigan State University) gave very important recommendations regarding the paper. The author is very thankful for their support.
} 
The existing paper are divvied in three groups that unite six topics:

The first group of literature is devoted to traditional ETF. There are two topics:

1. Is the ETF substitute for index mutual funds? If yes, to which level? If it is substitute, why it did not still the index funds?

2. Which influence has the introduction of an ETF on the active that it tracks. This topic covers also liquidity, hedge and arbitrage.

Second group of papers emerging recently unites the following topics:

3. How effective are the ETF tracking the foreign indexes?

4. ETF development besides USA.

5. ETF that track not the share indexes. New generation ETF: synthetic, leveraged, actively managed and smart-beta.

Third group of papers devoted to the following topic:

6. ETF use for optimal portfolio construction.

Keywords: ETF, exchange-traded funds, ETF literature review, ETF survey, index investing, portfolio optimization

JEL: G02, G11, G15

\section{Introduction}

The development of the exchange-traded funds market impresses by its dynamics. In December, 2014, the total value of ETFs' asset under management (AUM) reached 2.64 trln. USD (Fig. 1), with the annual trade volume of $18 \mathrm{trln}$. USD. In the USA, for several years approximately a quarter of equity trade volume consisted of ETFs' shares.

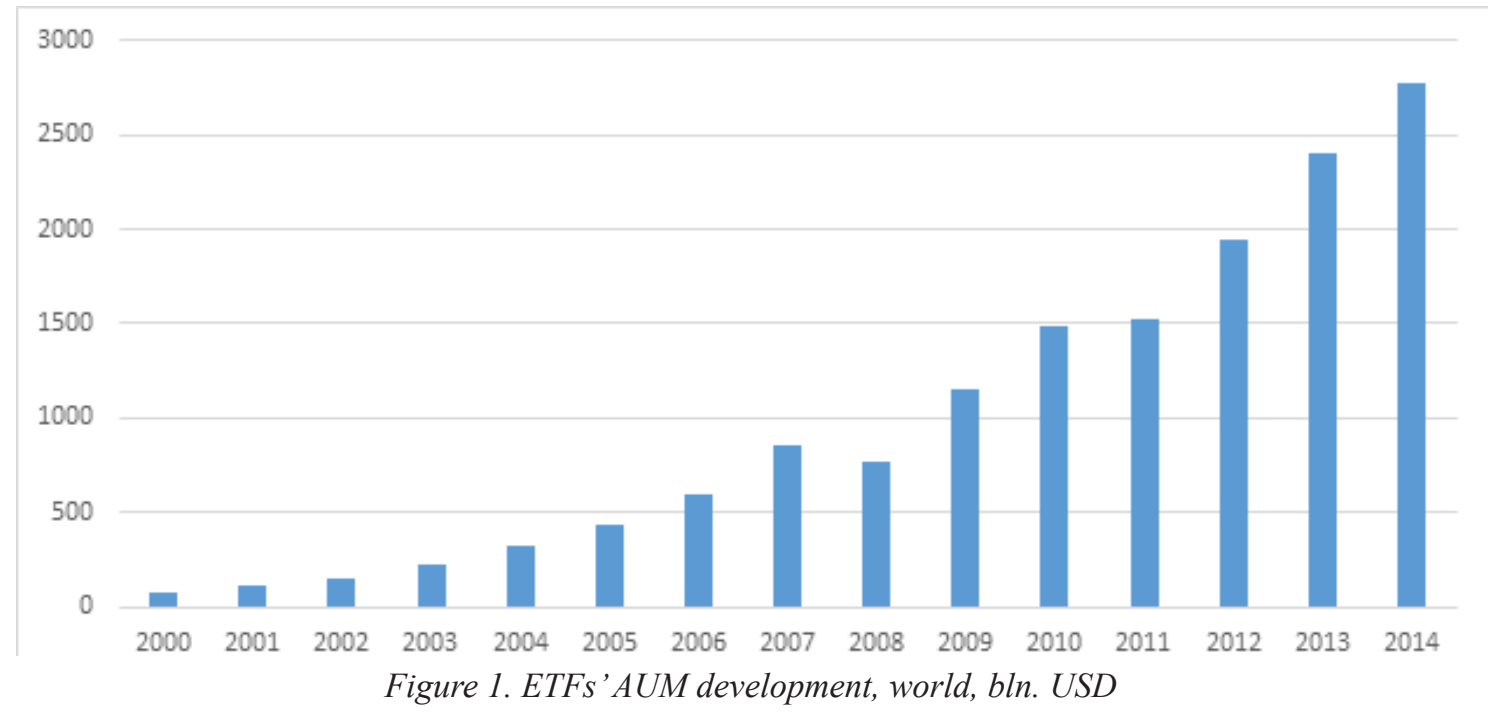

Source: Deutsche Bank ETF industry annual report 2014.

Currently, investors in most countries can trade ETFs on their domestic markets (Tab. 1).

Table 1

ETF trade volume (above one mln. USD), 2014, (mIn. USD)

1.1. Europe and USA

\begin{tabular}{|c|c|c|c|c|c|}
\hline Country & Trade volume & Country & Trade volume & Country & Trade volume \\
\hline UK & 158826 & Switzeland & 58165 & Norway & 4237 \\
\hline Germany & 134377 & Holland & 20901 & Portugal & 336 \\
\hline France & 67608 & Sweden & 12589 & Europe others & 166 \\
\hline Italy & 66065 & Spain & 4367 & USA & 16181566 \\
\hline
\end{tabular}




\subsection{Asia-Pacific}

\begin{tabular}{|c|c|c|c|c|c|}
\hline Country & Trade volume & Country & Trade volume & Country & Trade volume \\
\hline China & 518267 & Taiwan & 11681 & New Zeeland & 58 \\
\hline Japan* & 228014 & India & 2337 & Philippine & 6 \\
\hline Korea & 150316 & Singapure & 1397 & Malaysia & 2 \\
\hline Australia & 13354 & Tailand & 103 & Indonesia & 1 \\
\hline
\end{tabular}

\subsection{Other countries}

\begin{tabular}{|c|c|c|c|c|c|}
\hline Country & Trade volume & Country & Trade volume & Country & Trade volume \\
\hline Canada & 167495 & South Africa & 2304 & Saudi & 60 \\
\hline Mexico & 94570 & Namibia & 692 & Mauricio & 6 \\
\hline Brazile & 11180 & Columbia & 870 & Abu-Dhabi & 2 \\
\hline Botswana & 8866 & Chili & 100 & & \\
\hline
\end{tabular}

*As the legislation had allowed Japanese pension funds to invest in ETFs in 2014, the largest pension fund, GPIF (AUM 1,2 trln. USD,) started investing in ETF showing the new potential fund source for this asset class.

Source: Created by the author based on the Deutsche Bank ETF industry annual report 2014.

Russia is still not on the list of countries where the annual volume of ETF trades is above one million USD. At the same time, exchange-traded funds became the most popular financial instrument among the Russian mutual fund industry. The way of investing is, however, unusual: unlike other countries, where people invest in ETFs directly, in Russia investors do it via domestic mutual funds (MF). However, when investing for 10 years in an ETF via a Russian fund of funds, an investor pays up to $36 \%$ of invested capital more in commissions than someone who invests in the same ETF directly (Tab. 2).

Table 2

Extra payment (as a percent of the invested capital) for investing in an ETF via a MF compared to direct investing.

\begin{tabular}{|c|c|c|c|}
\hline Investment period, years & 1 & 5 & 10 \\
\hline Extra payments, \% of the invested capital & $4-7 \%$ & $14-18 \%$ & $27-36 \%$ \\
\hline
\end{tabular}

For the last two years (2014-2015), the absolute majority of the funds of funds have changed their investment strategy completely. Since then they have been investing only in one preselected western ETF out of the TOP 100 [Tarassov, 2016a]. During the same period, the group "funds of funds" has raised more money than any other fund category in Russia (Tab. 3).

Open-end MFs netflow, (mln. rubles $\left.{ }^{3}\right)$

\begin{tabular}{|c|c|c|c|}
\hline MF category & $\mathbf{2 0 1 4}+\mathbf{2 0 1 5}$ & 2014 & 2015 \\
\hline Equity & -12561 & -6973 & -5588 \\
\hline Bonds & -30278 & -33985 & 3707 \\
\hline Mixed & 4942 & 1086 & 3856 \\
\hline Money market & -444 & 597 & -1041 \\
\hline Index & -1358 & -1116 & -242 \\
\hline Fund of funds & 6176 & 5794 & 382 \\
\hline
\end{tabular}

Sources: National League of Management Companies, http://www.nlu.ru/pifs-privlechenie.htm1, February, 2016

${ }^{3}$ Ruble/USD $=70(12.12 .2015)$ 
The business literature is rich with analytical and other kinds of reports about exchange-traded funds. BlackRock and Deutsche Bank produce these on a regular basis. MorningStar, Investment Company Institute and ETF.com have many data on their websites. The Federal Reserve has been providing statistics on exchange-traded funds in its annual reports since 1993. The most comprehensive book on ETFs is probably that published by CFA (2015).

In 2006, five years after the emergence of the first academic literature on ETFs, Laurent Deville wrote a survey «Exchange Traded Funds: History, Trading and Research» ${ }^{4}$.

The author divides the research published at that time into four groups:

1. Does the ETF structure allow more effective index fund pricing?

2. Are ETFs an alternative to index mutual funds?

3. How do exchange-traded funds influence the market quality and volume of underlying assets and their derivatives?

4. All other questions, including competitions among stock exchanges and possible ways of applying ETFs.

Besides the academic literature review, Deville describes in detail the history of the ETF market, the fund's operating mechanism and future research perspectives.

Deville's survey covered most directions investigated in the papers published before 2006. Since then, new research came out searching for answers both to the new and to the previously stated questions.

Charupat and Miu [2013] partly filled this gap. The authors covered research devoted to ETF price efficiency, tracking error estimation, and the fund's effect on underlying assets and their derivatives.

Madhavan [2014] focused mostly on research investigating recently emerged products: actively managed funds, leveraged and so-called smart-beta products.

This literature review is a logical supplement to the three previously published surveys. The paper introduces an alternative literature classification, covers articles not included in earlier published reviews, and suggests some additions in ETF type's classification and systematization of the market development stages. The survey provides a brief history of the market and a description of the fund working mechanism. Additionally, in conclusion, some ideas for further research are proposed.

The existing ETF research is divided in three groups that unites six research areas:

The first group is devoted to a traditional ${ }^{5}$ ETF. It includes two areas:

Area 1. Are ETFs a substitute to index mutual funds? If yes, than to what extent? If the ETF is a substitute and is more convenient and less expensive, why do investors continue buying index mutual fund units?

These questions are reviewed from several angles: tax effectiveness, performance, transaction costs and tracking error.

Area 2. How do ETFs influence underlying assets of an index they track? This area also includes such topics as liquidity, arbitrage and hedging.

The second group of papers that is relatively new unites three areas:

Area 3. How effective are the ETFs that track foreign ${ }^{6}$ indexes?

Area 4. The ETF market development outside of the USA.

Area 5. ETFs other than those reflecting equity indexes. The introduction of a new generation funds: synthetic, actively managed, leveraged and so-called "smart-beta" products.

\footnotetext{
${ }^{4}$ Published in "Handbook of Financial Engineering" (2008).

${ }^{5}$ Traditional ETF physically buys underlying assets of an index.

${ }^{6}$ For an investor based in the USA
} 
The third group of research covers:

Area 6. The application of ETFs for optimal portfolio construction.

As Deville noted, despite the extensive business literature devoted to ETFs, academic research did not pay practically any attention to these funds until 2000. Just after the NASDAQ ETF introduction, the situation changed. However, the quantity of research papers is not comparable with that of the ETF business literature.

Table 4

Numbers of academic papers published classified by areas (up to Q1 2015).

\begin{tabular}{|c|c|c|c|c|c|c|c|c|c|c|c|c|c|c|c|c|c|c|c|}
\hline Area lyear & Total & 2001 & 2002 & 2003 & 2004 & 2005 & 2006 & 2007 & 2008 & 2009 & 2010 & 2011 & 2012 & 2013 & 2014 & 2015 \\
\hline 1 & 31 & 4 & 5 & 2 & 4 & 1 & 2 & & 3 & 2 & 5 & 2 & 1 & & & \\
\hline 2 & 21 & & & 1 & 1 & & & 1 & 2 & 2 & 4 & 4 & 3 & 2 & 1 & \\
\hline 3 & 7 & & & & & 1 & & 3 & 1 & & & & 2 & & & \\
\hline 4 & 22 & & 1 & 1 & 3 & 1 & 1 & & 3 & & 6 & 1 & 3 & 1 & 1 & \\
\hline 5 & 26 & & & & & 1 & 3 & & 1 & 2 & 3 & 6 & 4 & 2 & 2 & 2 \\
\hline 6 & 10 & & & & & 2 & & & 1 & & 3 & 1 & 1 & 1 & & 1 \\
\hline
\end{tabular}

Source: created by the author based on Scholar.google.com. First 50 pages "Exchange traded funds" search results.

This paper has four parts. The first one describes the history and current ETF market development. This part also briefly describes how a typical ETF functions. The second part reviews papers of the most frequently researched areas - ETFs versus index mutual funds, and the issues of liquidity, arbitrage and hedging. Research into the influence of ETFs on the underlying assets is also included in this part. The next part is devoted to the second group of academic papers that investigates the ETFs consisting of foreign assets, the market development outside the USA and the increased product range. The last part of the survey covers the papers about the application of ETFs for portfolio construction. Several suggestions for further research are included in the conclusion.

\section{ETF: emergence, development, current state and working mechanism}

\section{Emergence and development}

The idea to have an opportunity to buy or sell a portfolio in one trade used to be popular among a part of the market participants many years ago. Based on Gastineau [2002] and Deville [2008] a brief history of ETF market development is as follows.

The first modern portfolio trades took place among large investors at the end of the 1970s. Mostly these portfolios consisted of companies' equity included in S\&P 500. It took ca. 10 years until a North American small investor had the possibility to buy such a portfolio in one trade. Although the products were successful, they could not overcome legal barriers in the USA, and only continued to be available in Canada.

After the break, in 1993, the first modern exchange traded fund was listed on the American Stock Exchange, (AMEX). Currently, this first ETF, SPDR S\&P 500 ETF (Standard \& Poor's Depositary Receipts), is the most tradable security in the world (the 2014 volume reached $5.32 \mathrm{trln}$. USD) and the largest ETF (215 bln. USD under management) ${ }^{7}$.

In three years, Barclays Global Investors introduced a series of ETF products - World Equity Benchmark Shares (WEBS), which were renamed later as iShares ${ }^{8}$ MSCI. WEBS started tracking MSCI indexes ${ }^{9}$. Thanks to WEBS investors received easy access to trade in portfolios consisting of foreign assets.

${ }^{7}$ Deutsche Bank. ETF industry annual report 2014.

${ }^{8}$ Since 2009 has belonged BlackRock.

9 Morgan Stanley Capital International. 
In 1999, US investors could choose among ETFs tracking not only S\&P 500, S\&P 400, MSCI, but also DJI ${ }^{10}$, NASDAQ 100 and sectoral S\&P. Researchers relate the trade volume explosion to the Cubes (Qubes, QQQ) introduction that tracks NASDAQ 100. In 2001, three ETFs that track S\&P 500, DJI and NASDAQ 100 were traded not only on AMEX but also on NYSE. Boehmer and Boehmer [2003] proved that this was the key factor responsible for a radical bid-ask spread cut.

Based on the ETF research [Gastineau, 2002; Deville, 2008; Boehmer and Boehmer, 2003; Madura and Richie, 2005], the research discussing the Active versus Passive ways of investing [Fama and French, 2010; Gruber, 1996; Malkiel, 2005; Bogle, 2002], the BlackRock, Deutsche Bank, Investment Company Institute, Morningstar reports, and Federal Reserve statistics (Fig. 3), the author suggested the following picture of the ETF market development (Fig.2).

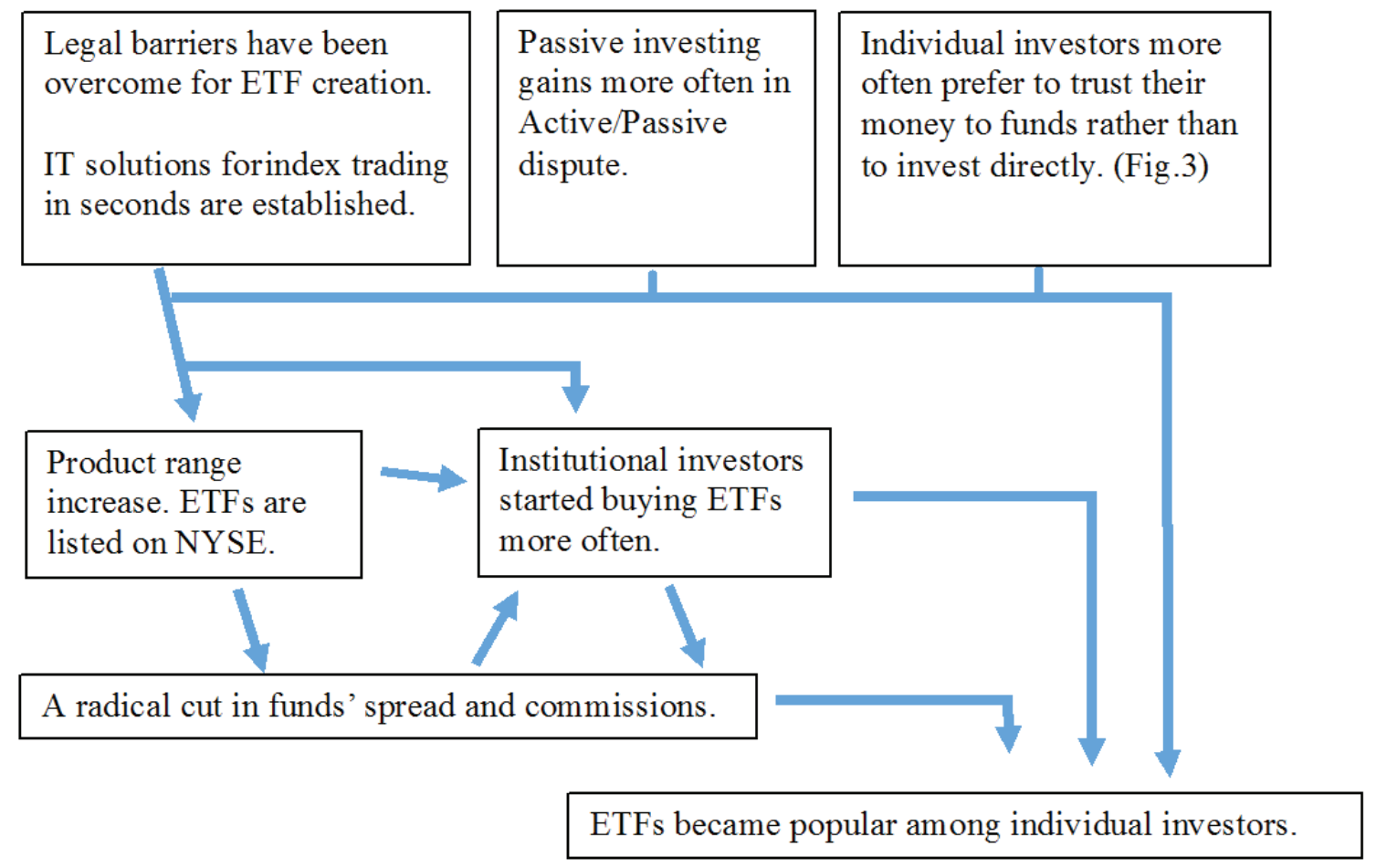

Figure 2. The stages of the ETF market development.

Source: created by the author

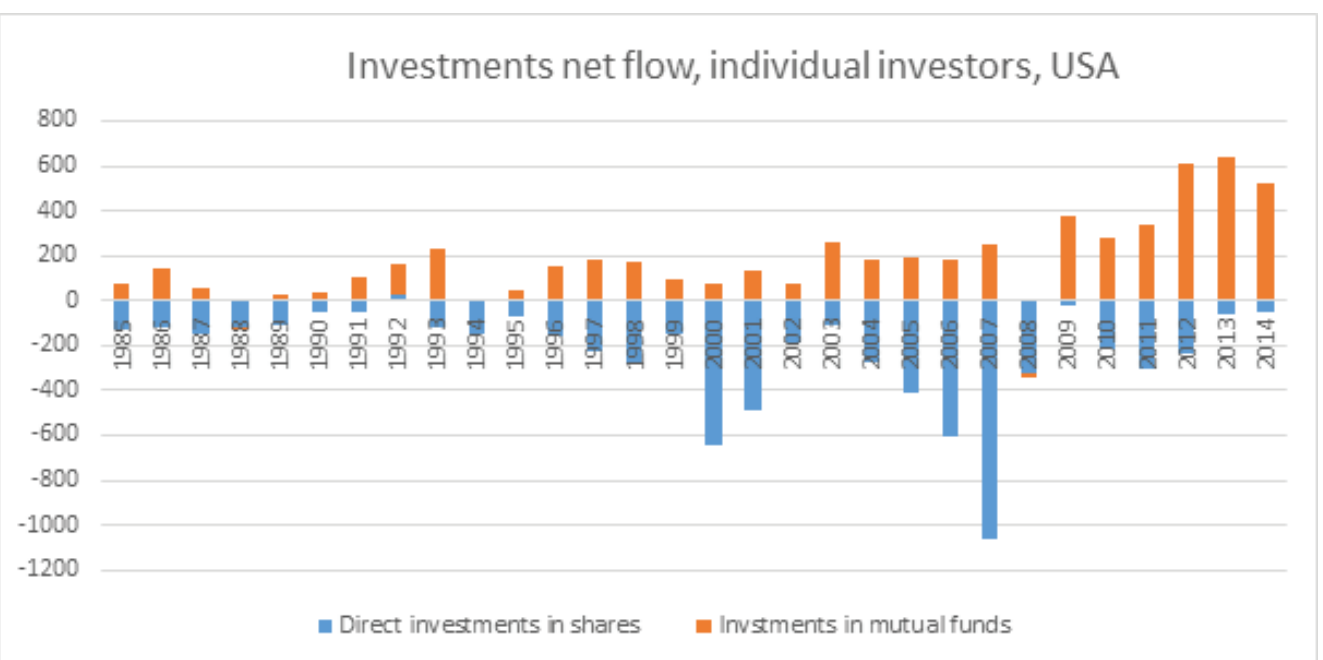

Figure 3. Individual investors' net flow, USA, bln. USD

Source: created by the author based on Federal Reserve USA statistics.

The ETF market today

In the 2000s the exchange trade funds gained popularity in the majority of the market economies (tab. 1 and 5).

${ }^{10}$ Dow Jones Industrial Average. 
AUM of the ETFs, regions

\begin{tabular}{|c|c|}
\hline Region & Bln. USD \\
\hline USA & 1920 \\
\hline Europe & 438 \\
\hline Asia-pacific & 201 \\
\hline Other countries, including Canada & 77 \\
\hline \multicolumn{2}{|c|}{ Sources: Deutsche Bank ETF industry annual report 2014. }
\end{tabular}

Last 10 years ETFs consist not only of companies' equity (tab.6).

Table 6

US Exchange-traded funds structure

\begin{tabular}{|c|c|}
\hline Asset class & Bln. USD \\
\hline Equity & 1601 \\
\hline Bonds & 312 \\
\hline Precious metal and natural resources $^{11}$ & 0,2 \\
\hline Others, including currency and real estate & 6,8 \\
\hline Sources: Deutsche Bank ETF industry annual report 2014.
\end{tabular}

Practically all ETFs are passively managed funds tracking an index ${ }^{12}$.

The largest coverage in the business literature belongs to funds suggesting their own index construction criteria: weights, dividends, Sharpe ratio etc. This category received the name "smart-beta" funds. Their AUM reached $410 \mathrm{bln}$. USD. Another type of fund, "leveraged", has $23 \mathrm{bln}$. USD under management.

However, the largest part of funds, with AUM 1165 bln. USD, simply reflects the established indexes. These funds might be called classical funds.

There are 3906 registered ETFs in the world. 407 started in 2014.

\section{Brief working mechanism description}

Based on Gastineau [2001], Deville [2008] and Investment Company Institute reports it is possible to describe the working mechanism of a traditional ETF as follows (Fig. 4).

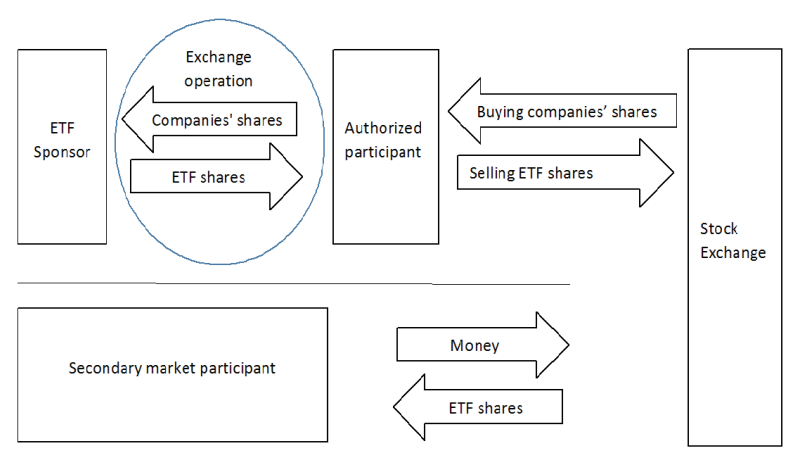

Figure 4. In-kind operation

Source: created by the author

Each fund is organized by the fund's sponsor, that establishes cooperation with Authorized Participants (AP) - large market operators. In 2014, funds that have $90 \%$ of all ETF AUM were organized

11 Other funds tracking precious metals and natural resources prices (53 bln. USD) are ETF type funds that are not included in ETF statistics because of some legal nuances (please see the working mechanism description).

12 Actively managed funds' AUM is 2,7 bln. USD. 
by fifteen sponsors (BlackRock, State Street Global Advisors, Vanguard etc.). There are 52 sponsors. Each fund has 34 APs on average ${ }^{13}$.

There are two markets: the market between sponsors and APs and a secondary market. Any investor can buy or sell ETF shares on the secondary market as she does with shares in other companies. 90\% of ETF trade takes place on the secondary market ${ }^{14}$.

A sponsor and its AP exchange large modules of ETF shares for companies' shares. It is an 'in-kind' buy or sell operation.

Thus, an AP has arbitrage possibility. When demand for an ETF's shares drives its prices up, the AP, buys underlying companies equity and exchanges it for ETF shares to sell them on the secondary market. This operation pushes the difference between the ETF price and that of underlying asset to a minimum. This mechanism practically guarantees negligible tracking error in most cases in the high liquidity fund sector.

The second advantage of such a mechanism is that an ETF, unlike a mutual fund, does not regularly calculate client's profit and so does not pay capital gains tax every quarter ${ }^{15}$.

The third important difference between an ETF and a mutual fund is the relatively lower fund administration costs. An ETF, unlike a mutual fund, does not keep a client's files. A practical absence of the bid-ask spread in the high liquidity fund sector drives investors' expenses even further down.

An investor's profit from investing in a fund (ETF or MF) can be expressed as:

$N P=C G-\sum T-\sum O C-$ spread $\pm \varepsilon ;$

$N P$ - net profit; CG - capital gain - price difference between fund's unit/share price at the moment of buying and at the moment of selling;

$\sum T=\operatorname{Tax} 1+\operatorname{Tax} 2$

Tax 1 - capital gains tax, calculated quarterly;

Tax 2 - capital gains tax, calculated after a fund's units/shares are sold;

$\sum \operatorname{Exp}=\operatorname{Exp} 1+\operatorname{Exp} 2+\operatorname{Exp} 3($ expences $):$

Exp 1 - custody and broker commission;

Exp 2 - front-end and back-end;

Exp 3 - management fees;

spread is a difference between price of buying and selling at one given moment;

$\varepsilon$ - tracking error;

In an ETF, in contrast to an MF: $\operatorname{Tax} 1=0, \operatorname{Exp} 2=0$.

The working mechanism, showed previously, is typical for the funds that physically buy assets included in the index the fund reflects. Usually such funds are called traditional funds.

For funds, that do not buy assets in a physical sense, the market developed the name "synthetic". To create such funds, a sponsor uses swaps, derivatives or statistical methods to mirror the prices of underlying assets.

Goltz and Tang [2010] described the working mechanism and other detailsof synthetic exchangetraded funds. It is important to note that some of these relatively new products cannot be called ETFs in many countries. Due to legislation of these countries, these products receive the name ETP (Exchange Traded Products). In such classification, ETFs are a part of ETPs. In general, Exchange Traded Products consist of Exchange Traded Notes (ETN), Exchange Traded Commodities/Curren-

\footnotetext{
${ }^{13}$ Investment Company Institute 2015.

${ }^{14}$ Investment Company Institute 2015.

${ }^{15}$ This procedure is not typical for all countries.
} 
cies (ETC) and Exchange Traded Vehicles (ETV). The largest ETF sponsor, BlackRock (1.02 trln. AUM and 38.7\% market share), started calling its analytics the Global ETP industry overview. On the other hand, Deutsche Bank continues calling its reports the ETF industry annual reports. However, its reports include research about ETP.

AUM of all ETP excluding ETF are 0.08 trln. USD.

Before proceeding with the literature review, let us fix the classification of exchange-traded funds (Fig. 5).

\section{Depends on the indexes tracked}

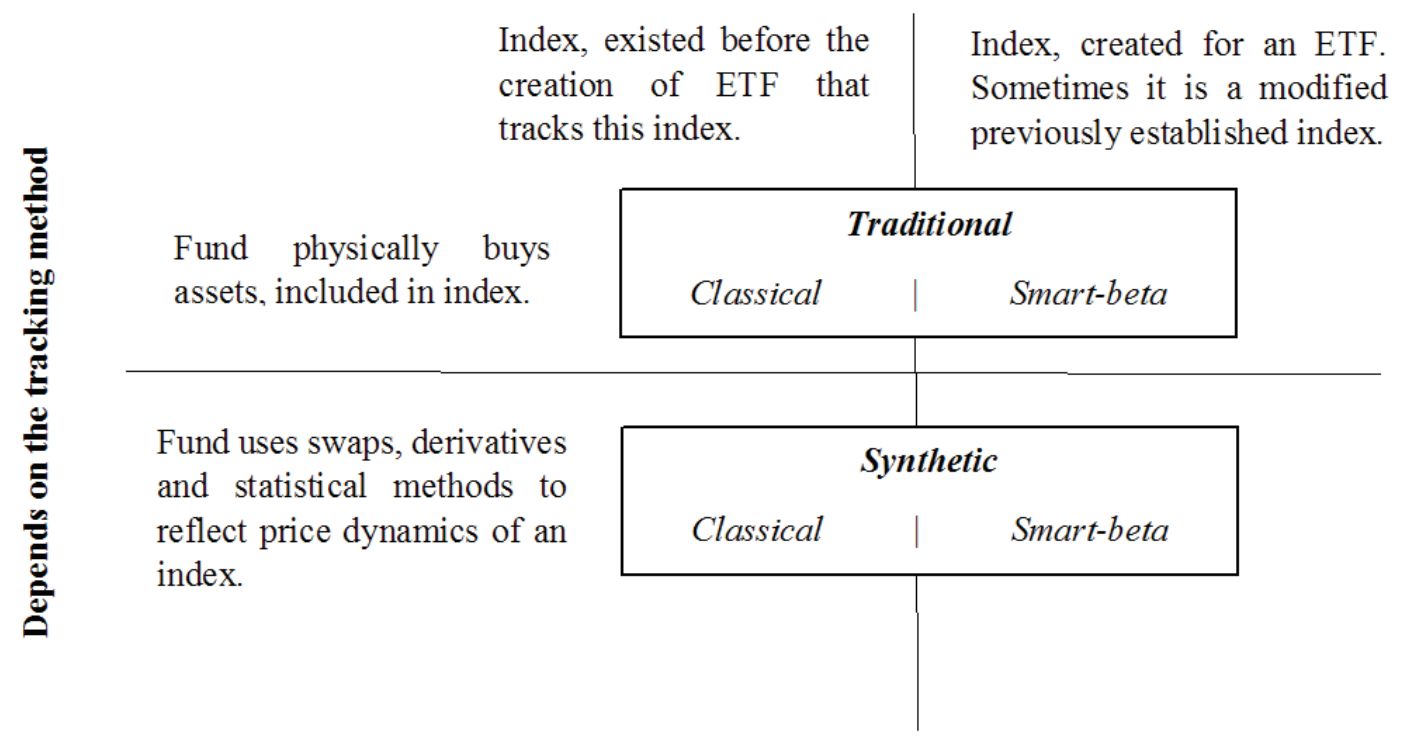

Figure 5. Exchange-traded funds classification

Source: created by the author.

\section{Classical traditional ETFs and the main related issues}

\section{An ETF versus an identical index fund}

Taxes and performance. One of the major differences between a MF and an ETF is that a MF needs to distribute its profit quarterly ${ }^{16}$ [Guedj and Huang, 2010]. In addition, it is impossible to reduce the capital gains tax by previous losses. Despite this fact, Poterba and Shoven [2002] demonstrated that performance after taxes of the largest ETF (SPDR) and the largest MF (Vanguard) are practically identical. (Both funds reflect the dynamics of S\&P 500). In the same year, Elton, Gruber, Comer and Li [2002] published results showing that the Vanguard index 500 fund's performance before taxes was stronger than that of SPDR. The authors tried to find the possible reasons.

Firstly, an ETF holds dividends on accounts that do not bear interest and they do not reinvest them immediately in the way a MF does. The researchers calculated that this factor could play an important role for long-term investment. Secondly, the management fee of the Vanguard fund is less than that of SPDR. Thirdly, the tracking error of SPDR was found to be larger. However, the authors continued with the disadvantages of a MF. For example, a MF has to keep some reserves available for the situations when investors may want to sell their units. In general, MF's administration expenses are larger than these of an ETF. A MF has to keep books of every client.

Both of these papers [Elton, Gruber, Comer and Li, 2002; J. Poterba and J. Shoven, 2002] are cited very often when investigating ETF taxes and performances. However, these two papers use the data

${ }^{16}$ USA. Some countries do not have this rule. 
for the period of 1993-2000. Just after this period, ETF expenses decreased dramatically [Boehmer and Boehmer, 2003].

Gastineau [2004] responding to these papers argues that the reasons for the lower SPDR performance lie in the situation that an ETF could not ignore the trade demand at the end of a day (as opposed to a MF). Sometimes, the trades at the day end have the potential to perturbate the index tracking, particularly during the changes in the index itself. The author finds this to be a temporary problem. He also presents data showing, that after the period studied in those both papers the SPDR performance before taxes became better than that of Vanguard index 500 fund.

Several years later, Svetina [2010] also demonstrated results opposite to the finding of the first period of the ETF research (1993-2002). He concluded that ETFs for retail clients generally outperformed the identical MFs and that for institutional investors demonstrated performance similar MFs. The author also added that ETFs did not need to hold dividends on a current account anymore. Furthermore, Svetina noted that only $17 \%$ of all ETFs compete with identical MFs. The other $83 \%$ tracks indexes that are not tracked by MFs. However, he did not mention the AUM of those two ETF groups.

Transaction costs and tracking error. In the second period, starting in 2003, several researchers (Kostovetsky, Svetina, Boehmer and Boehmer), having indicated that ETF transaction costs and tracking error had become lower than those of MFs, investigated the possible reasons for this. Firstly, it is not necessary to keep accounts for each client and there are practically no costs on shares exchange between the sponsor and its APs. The authors consider the decline of spreads and brokers' commissions to be the next reason. The last reason, based on their analyses, is the tracking error that had become much lower by that time.

Madura and Richie [2005] researched the reasons for tracking error from other perspectives. They demonstrated that one of the major reasons for a sometimes quite remarkable tracking error is investors' overreaction. During the dotcom boom and the following crises, the changes in ETF prices sometimes reached $5 \%$ in a matter of seconds. This proved that ETFs became popular among uninformed investors and from then on, fluctuations in ETF shares prices demonstrated the same dynamics as other instruments popular among uninformed investors. Chau, Deesomsak and Lau, (2011), after having investigated the emotional reaction of the holders of three largest ETFs to various news, concluded that investors' psychological mood has a significant influence on the ETF share prices.

ETF have still not replaced index funds. What are the reasons? Several papers have this question in their titles. Kostovetsky [2003] calculated that index mutual funds do not have financial advantages. However, having not answered the main question, he supposed that ETFs' advantages might play a substantial role in the future for the choice between these two instruments. The author mentioned the following important advantages of exchange-traded funds:

- Possibility to trade during a day. (MF could be bought or sold only once per day). Despite the opinion that long-term investors might not be interested in this feature, Kostovetsky suggested that, in days of crisis, a substantial part of them would prefer to sell their MF units at the beginning of the fall in share prices. Besides, they might prefer not to give an order to buy MF units in the evening but to wait until the morning to see the development. A sharp increase in ETF volume in days of crisis demonstrates that the possibility to trade during a day might be important also for long-term investors.

- $\quad$ A simple way of investing. One only needs to open a discount broker account and then can make an on-line trade.

- $\quad$ The possibility to put various trade limits.

- $\quad$ The possibility of short selling and using leverage.

Why then have ETFs not yet replaced MFs tracking the same index? Guedj and Huang [2009] developed another model to analyze the probability of that replacement. They noted that a difference between the liquidity level of an ETF and an identical MF does not influence the investors' choice. Agapova [2011] concluded that an ETF and an identical MF are substitutes, but not complete. She 
divided clients into three segments based on their liquidity needs, tax regimes, and frequency of trading. Furthermore, the author, explaining why, for some clients, the advantages of ETF are not important, demonstrated that client effect placed these two fund types in different market niches.

\section{ETF influence on underlying assets. Liquidity, hedging and arbitrage}

After the introduction of an ETF tracking DJI, the liquidity level of underlying assets increased [Hedge and McDermott, 2004]. The authors noted that the liquidity of the ETF became even higher than that of the underlying assets themselves. In general, derivatives' trade volume also increased. Additionally, their prices become more "fair", first, thanks to an increased liquidity level [Deville, Gresse, Severac, 2009] and effective arbitrage mechanism [Gastineau, 2001]. Camalia, Deville and Riva [2014] proved that possible liquidity problems in days of crisis could happen to ca. $20 \%$ of ETFs with the lowest day volumes. Their model shows that the ETF's liquidity level depends not only on the liquidity of underlying assets but also on several characteristics of the ETF itself, first of all, on its daily trade volume.

During the period 1998-2001 prices of ETFs and their underlying assets needed on average ten minutes in the USA and three hours in other countries to become equal [Engel, Sarkar, 2002]. During 2001-2010, it needed less than five minutes on average for SPDR tracking error to become practically equal to zero [Marshall, Nguyen, Visaltanachoti, 2013]. In this period, arbitrage operations resulted in earning of $6.7 \%$ p.a. on average. With an increase in the product range, the introduction of leveraged products and listing of ETFs on even more stock exchanges, the number of arbitrage opportunities will only increase.

Alexander and Barbosa [2008], having investigated hedging possibilities against the possible volatility of the largest ETFs, developed a system for minimizing the risks. In particular, the authors focused on price changes around dividend payments days.

\section{Geographical expansion and the new generation products}

$$
\text { ETFs, tracking foreign }{ }^{17} \text { assets }
$$

Continuing with liquidity and arbitrage issues, Ackert and Tian [2008] found that the liquidity level of funds tracking foreign assets is lower than that of those tracking major American indexes. The authors also demonstrate that a lower liquidity level results in lower arbitrage possibilities. Ackert and Tian concluded that the mechanism that minimizes tracking error in such cases does not work correctly. They calculated that this mechanism has a U-shaped function depending on liquidity and works to full potential only after the trade volume reaches a certain level.

Svetina [2010] and Poterba and Shoven [2002], prove that, in general, the effectiveness of ETFs tracking foreign assets is lower than that of funds reflecting domestic stocks. The authors mention the following possible reasons: tax retention from dividend payments in the issuer-country, lower liquidity, substantially larger tracking error, time difference and higher transaction costs.

ETFs tracking global emerging markets have an even larger tracking error. In addition, if, in order to lower transaction costs and overcome liquidity constraints, a fund is organized in a synthetic way, its tracking error is even higher [Blitz, Huij, 2012]. However, classical ETFs reflecting global indexes have a better Sharp ratio than identical MFs [Harper, Madura, Schnusenberg, 2006].

Huang and Lin [2011] concluded that there is no important difference in performance between direct investing in foreign assets directly, investing via index MFs or via ETFs.

Miffre [2007] notes that the ETFs, in addition to providing an investor with very high international diversification level, have another very important advantage, compared to the MFs, - the possibility of short selling.

${ }^{17}$ Foreign for a USA based investor. 


\section{ETF market development outside the USA}

As shown in table 1, ETFs are traded on the majority of stock exchanges. There is research into how the domestic ETFs perform in many countries. Most of these papers come to a similar conclusion regarding the performance of domestic ETFs and the positive influence on domestic markets. European research, in additional, focuses on new generation products and the application of ETFs for portfolio optimization [Deville et al., 2003; Deville et al., 2009; Deville et al., 2014; Musavian, Hirsch, 2002; Simon, Sternberg, 2005; Rompotis, 2012; Zanotti, Russo, 2005]. The authors demonstrate that many European ETFs have a larger tracking error than the US ETFs, supposing that this is the result of the non-traditional structure of the funds.

Chu [2011] also finds that tracking error on the Chinese market is, in general, larger than that in the USA. In addition to "standard' issues, Yao [2012] investigates conflicts of interest, manipulation and insight problems on the Chinese ETF market. Finally, another peculiarity of the Chinese ETF market is that several research papers, discussed below, are devoted to gold ETFs, which is not typical for developed markets.

\section{ETFs that reflect price dynamics of assets other than equity. New generation funds: actively managed, leveraged, synthetic and "smart-beta"}

ETF, tracking precious metals and natural resources price dynamics. The papers devoted to gold ETFs came from studies of the Chinese and Indian markets. Mukesh, Vikrant and Sougata [2012] add that gold ETFs are not only a convenient way of investing but useful because of their negative correlation with equity. Lixia, Iftikhar and Adnan [2010] produced an overview of the gold ETF development in China and estimated their perspectives. Both of them describe advantages of using gold funds for optimal portfolio construction. The papers describing issues in the natural resources ETFs (first of all "oil ETFs") are found only in business literature at the moment.

Leveraged ETFs are used mostly for intraday trade and have a major impact on tracking error, particularly at the day end. Most people who invest in leveraged ETFs are individual investors [Charupat, Miu, 2011].

Synthetic ETFs are more popular in Europe. While in general, synthetic funds show larger tracking error, there are funds where "synthetic way" is better. In the low trade volume fund sector synthetic funds have lower tracking error than identical traditional ETFs [Naumenko, Chystyakova, 2015] and a higher liquidity level than underlying assets [Camalia, Deville, Riva, 2014]. However, in general, the level of liquidity and transparency continues to be an object of criticism. European regulators try to find a compromise between defenders of synthetic and traditional ways of ETF structure [Millet, 2013]. However, since 2010 the industry has been returning to a traditional form, in particular in the area of equity funds. Competition for retail clients, who prefer better transparency, lowered the status of synthetic ETFs from the level they reached in 2006-2008 ${ }^{18}$. Goltz and Tang [2010] described the working mechanism and other details of this type of exchange-traded funds.

Actively managed exchange-traded funds not only confirmed the observations that active MFs do not outperform passive MFs [Gruber, 1996; Malkiel, 2005], but also demonstrated even worse overall return [Rompotis, 2009].

Currency ETFs. Ivanov [2015] investigates reasons of tracking error of these funds. The author calculated that spread, fund commissions and transaction costs are responsible for it. Ivanov suggests that his methodology is applicable to gold and natural resources funds. The author does not compare currency funds with other instruments.

«Smart-bets» ETFs. Madhavan [2014] describes in detail the working mechanism, methods of calculation of various indicators and advantages of such funds. He adds that creating index criteria for these ETFs is an intensive activity that means that such funds could be perceived as active funds.

Real estate ETFs. Curcio, Anderson, Guirguis and Boney [2012] prove that the volatility of underlying assets increased substantially after the introduction of an ETF.

${ }^{18}$ Deutsche Bank. ETF industry annual report 2013. 
Bond ETFs. Drenovak, Urosevic and Jelic [2012] demonstrate that, in general, bond ETFs have a notable tracking error. However, it is highly dependable on company, fund type and observation period. A further brief review of the literature on bond ETF follows.

\section{ETF for optimal portfolio construction}

De Freitas and Baker [2005] posed the question of whether exchange-traded funds themselves are a complex solution for optimal portfolio construction. In this paper, the authors gave a positive answer to this question. Furthermore, they devoted a special role in optimal portfolio construction to bond ETFs.

The application of exchange-traded funds for portfolio construction was found also in new paradigm - Core-Satellite Theory. Core-Satellite Theory, the paradigm that many leading investment companies (Goldman Sachs, UBS, Vanguard etc.) started following, divides a portfolio in two parts: core and satellites. The core consists of passive instruments like bond ETFs. The satellites invest in selected potentially more profitable and more risky strategies. According to a survey conducted in 2010, most investors, following this strategy, use ETFs in core [Goltz, Tang, 2010].

Amenc, Goltz and Grigorou [2010], describe the next stage of this method of portfolio construction - Dynamic Core-Satellite Theory. The dynamic application of bond and equity ETFs increases potential profit without adding new risks.

Puelz, Carvalho and Hahn [2015] analyze the latest trends in the wealth management industry sharp AUM increase in two companies: Wealthfront and Betterment. These companies offer automatic asset management using ETFs. The authors, having developed a model of picking the right exchange-traded funds, prove that one may build an optimal portfolio with a high Sharpe ratio by using a very limited number of ETFs.

\section{Conclusion and research suggestions}

Despite the increasing amount of academic research focused on ETFs, there are still several questions that are answered only partly or not covered at all.

There is still no answer to the most frequently posed question - why classical traditional ETFs have not yet replaced identical index mutual funds. One research direction might be an investigation of the differences between MFs' active marketing, including distribution channels, and the virtual absence of ETF marketing activities. For example, some MFs have a budget for incentivizing intermediaries while ETFs are not engaged in such activities. On the other hand, various countries introduce barriers for advisors to receive commission from product issuers. Moreover, there is a clear tendency in the remuneration system of independent advisors to evolve towards fixed commission paid by clients. The potential influence of these latest trends on the ETF market has not been studied yet.

There are no studies of the physiological aspect of the choice between MFs and ETFs. In general, the investor's attitude towards ETFs from a behavioral finance point of view has not yet been investigated. Tarassov [2016b] studies the relationship between people's predisposition to categorical thinking and non-optimal index investing, including choosing an index MF instead of an identical ETF, might be a small contribution to this area. Additionally, a lack of index-investing culture in countries with immature financial markets could be one of the reasons for even more widespread irrational behavior of investors, e.g. the Russian ETF anomaly [Tarassov, 2016a].

Another important question might be whether classical traditional exchange-traded funds, thanks to their transparency and absence of specific risk, could be attractive for investors who do not trust the stock market and invest only in saving deposits (other fixed income instruments) or real estate. While in the USA, where more than a half of households participate in the stock market (directly or via funds) ${ }^{19}$, such research might be less important, in countries where the stock market investors' share is at a minimal level such a study may probably have a stronger impact. What could be a trigger for capital owners, investing in real estate, to turn their attention to more liquid real estate ETFs?

\footnotetext{
${ }^{19}$ Investment Company Institute, 2014.
} 
Probably, constructing a model that would allow a comparison of direct investment in real estate with investment via an exchange-traded fund would be a challenging topic for research.

Another interesting topic for study is the application of ETFs for optimal portfolio construction in the concept of "passive management revolution" or in "focus shifting from a single security picking capabilities importance to importance of asset class choosing" 20 . The research into application of ETFs in Dynamic Core-Satellite Theory is a very good start in this direction.

The question about regulation regarding non-traditional funds remains slightly separate. So far, there is not yet a comparative study between different approaches in the USA and in Europe. Is it important to limit the industry only by classical traditional ETFs? Does trust in the ETF market decrease with an increase in the number of funds with complicated structure? Or, on the contrary, does a broader product range results in more attention to the ETF market?

There are no studies on how ETFs have been introduced in transition economies and why there are still stock exchanges without this type of funds. There is no research into ETFs' potential impact on these countries markets.

The author hopes that this survey in general, and the new way of literature classification, the emphasis on the systematic changes in empirical results obtained in studies published before 2001-2002 and afterwards, elaboration on the classification of funds, and definition of market development stages, in particular, might have a positive impact on future ETF research, and add transparency for the young ETF markets or new ETF investors.

\section{References}

1. Ackert L., Tian Y. (2008) Arbitrage, Liquidity, and Valuation of Exchange Traded Funds. Financial Markets, Institutions \& Instruments, vol. 17, no. 5, pp. 331-362.

2. Agapova A. (2010) Conventional Mutual Index Funds versus Exchange Traded Funds. Journal of Financial Markets, vol. 14, no. 2, pp. 323-343.

3. Alexander C., Barbosa A. (2008) Hedging index Exchange Traded Funds. Journal of Banking and Finance, vol. 32, no. 2, pp. 326-337.

4. Amenc N., Goltz F., Grigorou A. (2010) Risk Control through Dynamic Core-Satellite Portofolios of ETFs: Application to Absolute Return Funds and Tactical Asset Allocation. The Journal of Alternative Investments, vol. 13, no. 2, p. 47.

5. BlackRock Global ETP landscape (2014). Available at: www.blackrock.com.

6. Blitz D., Huij J. (2012) Evaluating the performance of global emerging market equity exchange-traded funds. Emerging markets review, vol. 13, no. 2, pp. 149-158.

7. Boehmer B., Boehmer K (2003) Trading your neighbor's ETFs: Competition or Fragmentation? Journal of Banking and Finance, vol. 27, no. 9, pp. 1667-1703.

8. Camalia A., Deville L., Riva F. (2014) The determinants of ETF liquidity: Theory and evidence from European Markets. Working paper, efmaefm.org.

9. Charupat N., Miu P. (2011) The pricing and performance of leveraged exchange traded funds. Journal of Banking and Finance, vol. 35, no. 4, pp. 966-977.

10. Charupat N., Miu P. (2013) Recent developments in exchange-traded fund literature. Managerial Finance, vol. 39, no. 5, pp. 427-443.

11. Chau F., Deesomsak R., Lau M. (2011) Investor sentiment and feedback trading: Evidence from exchange traded fund markets. International Review of Financial Analysis, vol. 20, no.. 5, pp. 292-305.

12. Chu P. K.-K. (2011) Study on the tracking orders and their determinants: evidence from Hong Kong exchange traded funds. Applied Financial Economics, vol. 21, no. 5, pp. 309-315.

${ }^{20}$ Deutsche Bank. ETF industry annual report 2014. 
13. Curcio R., Anderson R., Guirguis H., Boney V. (2012) Have leveraged and traditional ETFs impacted the volatility of real estate stock prices? Applied Financial Economics, vol. 22, no. 6, pp. 709-722.

14. De Freitas E., Baker C. (2005) ETFs - Tactical asset allocation tools. Exchange Traded Funds, Spinger, pp. 85-94.

15. Deville L. (2003) Impact de l'indroduction du tracker Master Share CAC 40 sur la parite call-put. Banque et Marches, vol. 62, no. 2 pp. 50-57.

16. Deville L. (2008) Exchange traded funds: history, trading and research. Handbook of Financial Engineering, Springer US, pp. 67-98. Deville L., Gresse C., Severac B. (2009) Direct and indirect impact of index ETF on spot-futures. mispricing and illiquidity. Working paper, University Paris-Dauphine.

17. Drenovak M., Urosevic B., Jelic R. (2012) European bond ETFs - tracking errors and sovereign debt crisis. European Financial Management (electronic journal). doi: 10.1111/j.1468-036X.2012.00649.x.

18. Deutsche Bank ETF industry annual report (2014). Available at: etf.deutscheawm.com.

19. Elton E., Gruber M., Comer G., Li K. (2002) Spiders: where are the bugs? Journal of Business, vol. 75, no. 3, pp. 453-473.

20. Engel R., Sarkar D. (2002) Pricing exchange traded funds. Working paper. Available at: stern.nyu.edu.

21. Fama E., French K. (2010) Luck versus skill in the cross-section mutual fund returns. The Journal of Finance, vol. LXV no. 5, pp. 1915-1947.

22. Fama E., French K. (2015) A five-factor Asset Pricing Model. Journal of Financial Economics, vol. 116, no. 1, pp. 1-22.

23. Federal Reserve. Available at: www.federalreserve.gov.

24. Frino A., Gailagher D. (2001) Tracking S\&P 500 index funds. Journal of Portfolio Management, vol. 28, no. 1, pp. 44-55.

25. Gastineau G.L. (2001) An introduction to exchange traded funds. Journal of Portfolio Management, vol. 27, no. 3, pp. 88-96.

26. Gastineau G.L. (2002) Equity Index Fund has lost their way. Journal of Portfolio Management, vol. 28 , no. 2, pp. 55-64.

27. Gastineau G.L. (2004) The benchmark index ETF performance problem. Journal of Portfolio Management, vol. 30, no. 2, pp. 96-103.

28. Goltz F., Tang L. (2010) The state of development of the European ETF industry after a decade: evidence from demand side. Bankers, Markets \& Investors, no. 109, no. 1, p. 57.

29. Gruber M.J. (1996) Another Puzzle: the Growth in Actively Managed Mutual Fundsю Journal of Finance, vol. 51, no. 3, pp. 783-810.

30. Guedj I., Huang J. (2009) Are ETFs Replacing Index Mutual Funds. AFA 2009 San Francisco Meetings Paper.

31. Harper J., Madura J., Schnusenberg O. (2006) Performance comparison between exchange traded funds and close end country funds. International Financial Markets, Institutions and Money, vol. 16, no. 2, pp. 104-122.

32. Hedge P., McDermott J. (2004) The market liquidity of DIAMONDS, Qs and their underlying stocks. Journal of Banking and Finance, vol. 28, no. 5, pp. 1043-1067.

33. Hill M., Nadig D., Hougan M. (2015) A comprehensive guide to exchange traded funds (ETFS). CFA Institute Research Foundation.

34. Huang M.Y., Lin J.B. (2011) Do ETF provided effective international diversification? Research in International Business and Finance, vol. 25, no. 3, pp. 335-344. 
35. Investment Company Institute, Available at: www.ici.com.

36. Ivanov S. (2015) Intraday analysis of currency ETFs. International Journal of Managerial Finance, vol. 11, no. 4, pp. 438-450.

37. Kostovetsky L. (2003) Index mutual funds and exchange traded funds. A comparison of two methods passive investment. Journal of Portfolio Management, vol. 29, no. 4, pp. 80-92.

38. Lixia W., Iftikhar H., Adnan A. (2010) Gold exchange traded funds: current development and future perspectives in China. Asian Social Science, vol. 6, no. 7, p 119

39. Madhavan A. (2014) Exchange-traded funds: an overview of institutions, trading, and impactsю The Annual Review of Financial Economics, vol. 6, pp. 311-341.

40. Madura J., Richie N. (2004) Overreaction in exchange-traded funds during the Bubble 19982002. Journal of Behavioral Finance, vol. 5, no. 2, pp. 91-104.

41. Malkiel B.G. (2005) Reflection of the efficient market hypothesis: 30 years later. The Financial Review vol. 40, no. 1, pp. 1-9.

42. Marshall B., Nguyen N., Visaltanachoti N. (2013) ETF Arbitrage: Intraday evidence. Journal of Banking and Finance, vol. 37, no. 9, pp. 3486-3498.

43. Miffre J. (2007) A country specific ETF: an efficient approach to global asset allocation. Journal of Asset Management, vol. 8, no. 2, pp. 112-122.

44. Millet F. (2013) ESMA earns strong credentials thanks to its convincing approach concerning ETF regulation. Journal of Securities Operations \& Custody, vol. 6, no. 1, pp. 10-11.

45. MorningStar (2012) Synthetic ETFs under the microscope: a global study. Available at: http://media.morningstar.com/eu/ETF/assets/SyntheticETFsUnderTheMicroscope AGlobalStudy_Morningstar.pdf

46. Mukesh K.M., Vikrant K., Sougata R. (2012) Gold ETF performance: a comparative analysis of monthly returnю UIP Journal of Financial Risk Management, vol. 9, no. 2, pp. 59-63.

47. Musavian M., Hirsch L. (2002) European Exchange Trading Funds: An Overview. Journal of Alternative Investments, vol. 5, no. 2, pp. 63-77.

48. Naumenko K., Chystiakova O. (2015) An empirical study on the differences between syntetic and physical ETFs. International Journal of Economics and Finance, vol. 7, no. 3, p. 24.

49. Poterba J.M., Shoven J.B. (2002) Exchange-traded funds: a new investment option for taxable investors. American Economic Review, vol. 92, no. 2, pp. 422-427.

50. Puelz D., Carvalho C., Hahn R. (2015) Optimal ETF selection for passive investing. Working paper. arXiv preprint arXiv:1510.03385.

51. Rompotis G.G. (2009) Active versus passive management: new evidence from exchange traded funds. Working Paper. Available at SSRN: http://dx.doi.org/10.2139/ssrn.1337708.

52. Rompotis G.G. (2012) The German Exchange Traded Funds. IUP Journal of Applied Finance, vol. 18, no. 4, pp. 62-82.

53. Simon, D.P., Sternberg, J.S. (2005) Overreaction and trading strategies in European iShares. The Journal of Alternative Investments, vol. 8, no. 1,p. 29.

54. Svetina M. (2010) Exchange traded funds: performance and competitions. Journal of applied finance, vol. 20, no. 2, pp. 130-145.

55. Tarassov E.B. (2016a) The Russian ETF anomaly and its possible reasons. Working paper, HSEy. Available at: https://www.researchgate.net/profile/Evgeni_Tarassov/contributions.

56. Tarassov E.B. (2016b) Non-optimal index investing, including the Russian ETF anomaly, and categorical thinking. Working paper, HSE. Available at: https://www.researchgate.net/ profile/Evgeni_Tarassov/contributions.

57. Vanguard (2010) Building a global core-satellite portfolio. Available at: www.vanguard. com/pdf/icrcs.pdf. 
58. Yao Y. (2012) The core issues of open-ended funds in China: conflict of interests and ownership structure. International Journal of Academic Research in Business and Social Science, vol. 2, no. 8, p. 443.

59. Zanotti G., Russo C. (2005) Exchange trading funds versus traditional mutual funds: a comparative analysis on the Italian market. Working Paper, Bocconi University.

\section{БИРЖЕВЫЕ ФОНДЫ (ЕТF $)^{21}:$ ИСТОРИЯ, МЕХАНИЗМ РАБОТЫ, ОБЗОР АКАДЕМИЧЕСКОЙ ЛИТЕРАТУРЫ И ПЕРСПЕКТИВЫ ИССЛЕДОВАНИЙ}

Тарасов Евгений Борисович 22 ,

Этот обзор является ответом на российскую ЕТF аномалию, демонстрирующую, как дорого может обойтись инвестору отсутствие биржевых фондов на домашнем рынке. Возможно, их отсутствие на московской бирже и, соответственно, отсутствие привычки работать с этим инструментом является одной из причин крупных переплат (до 36\% от капитала при инвестициях на 10 лет), которые российский инвестор делает при инвестировании в американские и европейские биржевые фонды через российские ПИФы.

Вместе с тем появление и стремительное развитие рынка биржевых фондов является одним из существенных изменений в финансовой индустрии за последние 20 лет. Данный обзор призван познакомить широкий круг российских читателей с этой важной финансовой инновацией, а также с основными направлениями научной литературы, посвященной изучению биржевых фондов. Кроме обзора широкого спектра академических исследований в работе приводится краткая история рынка ETF и описание механизма функционирования биржевых фондов. Эта статья дополняет три предыдущих обзора, одному из которых более 10 лет, а два других являются скорее узконаправленными. В дополнение в обзоре представлен альтернативный подход к классификации литературы. В заключительной части предложен ряд тем для дальнейших исследований.

Ключевые слова: биржевые фонды, ЕTF, ЕTF обзор, ETF обзор литературы, инвестиции в индекс, оптимизация портфеля, применяя ЕTF

JEL: G02, G11, G15

\section{Список литературы}

1. Ackert L., Tian Y. (2008) Arbitrage, Liquidity, and Valuation of Exchange Traded Funds. Financial Markets, Institutions \& Instruments, vol. 17, no. 5, pp. 331-362.

2. Agapova A. (2010) Conventional Mutual Index Funds versus Exchange Traded Funds. Journal of Financial Markets, vol. 14, no. 2, pp. 323-343.

3. Alexander C., Barbosa A. (2008) Hedging index Exchange Traded Funds. Journal of Banking and Finance, vol. 32, no. 2, pp. 326-337.

4. Amenc N., Goltz F., Grigorou A. (2010) Risk Control through Dynamic Core-Satellite Portofolios of ETFs: Application to Absolute Return Funds and Tactical Asset Allocation. The Journal of Alternative Investments, vol. 13, no. 2, p. 47.

5. BlackRock Global ETP landscape (2014). Available at: www.blackrock.com.

6. Blitz D., Huij J. (2012) Evaluating the performance of global emerging market equity

\footnotetext{
${ }^{21}$ Биржевые инвестиционные фонды. В русском языке наряду с названием «биржевые фонды» широко используется английская аббревиатура ETF (Exchange Traded Fund). Главное отличие паевого инвестиционного фонда (ПИФ) от биржевого (ETF) - паи ПИФ можно купить или продать один раз в день, согласно заранее поданной заявке, а акции биржевого фонда торгуются на бирже в режиме реального времени.

${ }^{22}$ Аспирант НИУ ВШЭ, 101100, Москва, ул. Мясницкая д. 20; руководитель ООО «Исследовательский институт управления крупным личным капиталом», 141400, Москва, Химки, ул. Энгельса, д. 10/19, оф. 9. E-mail: etarassovet@gmail.com
} 
exchange-traded funds. Emerging markets review, vol. 13, no. 2, pp. 149-158.

7. Boehmer B., Boehmer K (2003) Trading your neighbor's ETFs: Competition or Fragmentation? Journal of Banking and Finance, vol. 27, no. 9, pp. 1667-1703.

8. Camalia A., Deville L., Riva F. (2014) The determinants of ETF liquidity: Theory and evidence from European Markets. Working paper, efmaefm.org.

9. Charupat N., Miu P. (2011) The pricing and performance of leveraged exchange traded funds. Journal of Banking and Finance, vol. 35, no. 4, pp. 966-977.

10. Charupat N., Miu P. (2013) Recent developments in exchange-traded fund literature. Managerial Finance, vol. 39, no. 5, pp. 427-443.

11. Chau F., Deesomsak R., Lau M. (2011) Investor sentiment and feedback trading: Evidence from exchange traded fund markets. International Review of Financial Analysis, vol. 20, no.. 5, pp. 292-305.

12. Chu P. K.-K. (2011) Study on the tracking orders and their determinants: evidence from Hong Kong exchange traded funds. Applied Financial Economics, vol. 21, no. 5, pp. 309-315.

13. Curcio R., Anderson R., Guirguis H., Boney V. (2012) Have leveraged and traditional ETFs impacted the volatility of real estate stock prices? Applied Financial Economics, vol. 22, no. 6, pp. 709-722.

14. De Freitas E., Baker C. (2005) ETFs - Tactical asset allocation tools. Exchange Traded Funds, Spinger, pp. 85-94.

15. Deville L. (2003) Impact de l'indroduction du tracker Master Share CAC 40 sur la parite call-put. Banque et Marches, vol. 62, no. 2 pp. 50-57.

16. Deville L. (2008) Exchange traded funds: history, trading and research. Handbook of Financial Engineering, Springer US, pp. 67-98. Deville L., Gresse C., Severac B. (2009) Direct and indirect impact of index ETF on spot-futures. mispricing and illiquidity. Working paper, University Paris-Dauphine.

17. Drenovak M., Urosevic B., Jelic R. (2012) European bond ETFs - tracking errors and sovereign debt crisis. European Financial Management (electronic journal). doi: 10.1111/j.1468-036X.2012.00649.x.

18. Deutsche Bank ETF industry annual report (2014). Available at: etf.deutscheawm.com.

19. Elton E., Gruber M., Comer G., Li K. (2002) Spiders: where are the bugs? Journal of Business, vol. 75, no. 3, pp. 453-473.

20. Engel R., Sarkar D. (2002) Pricing exchange traded funds. Working paper. Available at: stern.nyu.edu.

21. Fama E., French K. (2010) Luck versus skill in the cross-section mutual fund returns. The Journal of Finance, vol. LXV no. 5, pp. 1915-1947.

22. Fama E., French K. (2015) A five-factor Asset Pricing Model. Journal of Financial Economics, vol. 116, no. 1, pp. 1-22.

23. Federal Reserve. Available at: www.federalreserve.gov.

24. Frino A., Gailagher D. (2001) Tracking S\&P 500 index funds. Journal of Portfolio Management, vol. 28, no. 1, pp. 44-55.

25. Gastineau G.L. (2001) An introduction to exchange traded funds. Journal of Portfolio Management, vol. 27, no. 3, pp. 88-96.

26. Gastineau G.L. (2002) Equity Index Fund has lost their way. Journal of Portfolio Management, vol. 28 , no. 2, pp. 55-64.

27. Gastineau G.L. (2004) The benchmark index ETF performance problem. Journal of Portfolio Management, vol. 30, no. 2, pp. 96-103.

28. Goltz F., Tang L. (2010) The state of development of the European ETF industry after a 
decade: evidence from demand side. Bankers, Markets \& Investors, no. 109, no. 1, p. 57.

29. Gruber M.J. (1996) Another Puzzle: the Growth in Actively Managed Mutual Fundsю Journal of Finance, vol. 51, no. 3, pp. 783-810.

30. Guedj I., Huang J. (2009) Are ETFs Replacing Index Mutual Funds. AFA 2009 San Francisco Meetings Paper.

31. Harper J., Madura J., Schnusenberg O. (2006) Performance comparison between exchange traded funds and close end country funds. International Financial Markets, Institutions and Money, vol. 16, no. 2, pp. 104-122.

32. Hedge P., McDermott J. (2004) The market liquidity of DIAMONDS, Qs and their underlying stocks. Journal of Banking and Finance, vol. 28, no. 5, pp. 1043-1067.

33. Hill M., Nadig D., Hougan M. (2015) A comprehensive guide to exchange traded funds (ETFS). CFA Institute Research Foundation.

34. Huang M.Y., Lin J.B. (2011) Do ETF provided effective international diversification? Research in International Business and Finance, vol. 25, no. 3, pp. 335-344.

35. Investment Company Institute, Available at: www.ici.com.

36. Ivanov S. (2015) Intraday analysis of currency ETFs. International Journal of Managerial Finance, vol. 11, no. 4, pp. 438-450.

37. Kostovetsky L. (2003) Index mutual funds and exchange traded funds. A comparison of two methods passive investment. Journal of Portfolio Management, vol. 29, no. 4, pp. 80-92.

38. Lixia W., Iftikhar H., Adnan A. (2010) Gold exchange traded funds: current development and future perspectives in China. Asian Social Science, vol. 6, no. 7, p 119

39. Madhavan A. (2014) Exchange-traded funds: an overview of institutions, trading, and impactsю The Annual Review of Financial Economics, vol. 6, pp. 311-341.

40. Madura J., Richie N. (2004) Overreaction in exchange-traded funds during the Bubble 19982002. Journal of Behavioral Finance, vol. 5, no. 2, pp. 91-104.

41. Malkiel B.G. (2005) Reflection of the efficient market hypothesis: 30 years later. The Financial Review vol. 40, no. 1, pp. 1-9.

42. Marshall B., Nguyen N., Visaltanachoti N. (2013) ETF Arbitrage: Intraday evidence. Journal of Banking and Finance, vol. 37, no. 9, pp. 3486-3498.

43. Miffre J. (2007) A country specific ETF: an efficient approach to global asset allocation. Journal of Asset Management, vol. 8, no. 2, pp. 112-122.

44. Millet F. (2013) ESMA earns strong credentials thanks to its convincing approach concerning ETF regulation. Journal of Securities Operations \& Custody, vol. 6, no. 1, pp. 10-11.

45. MorningStar (2012) Synthetic ETFs under the microscope: a global study. Available at: $\quad$ http://media.morningstar.com/eu/ETF/assets/SyntheticETFsUnderTheMicroscope_ AGlobalStudy_Morningstar.pdf

46. Mukesh K.M., Vikrant K., Sougata R. (2012) Gold ETF performance: a comparative analysis of monthly returnю UIP Journal of Financial Risk Management, vol. 9, no. 2, pp. 59-63.

47. Musavian M., Hirsch L. (2002) European Exchange Trading Funds: An Overview. Journal of Alternative Investments, vol. 5, no. 2, pp. 63-77.

48. Naumenko K., Chystiakova O. (2015) An empirical study on the differences between syntetic and physical ETFs. International Journal of Economics and Finance, vol. 7, no. 3, p. 24.

49. Poterba J.M., Shoven J.B. (2002) Exchange-traded funds: a new investment option for taxable investors. American Economic Review, vol. 92, no. 2, pp. 422-427.

50. Puelz D., Carvalho C., Hahn R. (2015) Optimal ETF selection for passive investing. Working paper. arXiv preprint arXiv:1510.03385. 
51. Rompotis G.G. (2009) Active versus passive management: new evidence from exchange traded funds. Working Paper. Available at SSRN: http://dx.doi.org/10.2139/ssrn.1337708.

52. Rompotis G.G. (2012) The German Exchange Traded Funds. IUP Journal of Applied Finance, vol. 18, no. 4, pp. 62-82.

53. Simon, D.P., Sternberg, J.S. (2005) Overreaction and trading strategies in European iShares. The Journal of Alternative Investments, vol. 8, no. 1,p. 29.

54. Svetina M. (2010) Exchange traded funds: performance and competitions. Journal of applied finance, vol. 20, no. 2, pp. 130-145.

55. Tarassov E.B. (2016a) The Russian ETF anomaly and its possible reasons. Working paper, HSEy. Available at: https://www.researchgate.net/profile/Evgeni_Tarassov/contributions.

56. Tarassov E.B. (2016b) Non-optimal index investing, including the Russian ETF anomaly, and categorical thinking. Working paper, HSE. Available at: https://www.researchgate.net/ profile/Evgeni_Tarassov/contributions.

57. Vanguard (2010) Building a global core-satellite portfolio. Available at: www.vanguard. com/pdf/icrcs.pdf.

58. Yao Y. (2012) The core issues of open-ended funds in China: conflict of interests and ownership structure. International Journal of Academic Research in Business and Social Science, vol. 2, no. 8, p. 443.

59. Zanotti G., Russo C. (2005) Exchange trading funds versus traditional mutual funds: a comparative analysis on the Italian market. Working Paper, Bocconi University.

\title{
АНАЛИЗ ВЛИЯНИЯ КОРПОРАТИВНОГО УПРАВЛЕНИЯ НА БАНКРОТСТВО РОССИЙСКИХ КОМПАНИЙ НА ОСНОВЕ МЕТОДА PARTIAL LEAST SQUARES PATH MODELING
}

\author{
Федорова Елена Анатольевна ${ }^{1}$, Зеленков Юрий Александрович²,
}

Чекризов Дмитрий Васильевич, Добрянская Полина Сергеевна ${ }^{4}$

Цель данной работы - выявление наиболее значимых факторов внешней и внутренней среды (к которой относятся финансовые показатели и качество корпоративного управления) для прогнозирования вероятности банкротства российских предприятий. Параметры (иногда их называют также латентными переменными) «внешняя среда», «корпоративное управление» и «финансовое состояние» невозможно измерить непосредственно, поскольку они недостаточно четко определены. В таком случае обычно используют измеряемые индикаторы, которые связаны с латентными переменными линейными зависимостями. Вид этих зависимостей можно определить на основе метода PLS-PM (Partial Least Squares - Path Modeling). Эмпирическая база исследования включала 376 публичных российских компаний. На основе проведенного анализа было выявлено, что самое большое влияние на вероятность банкротства предприятия оказывает внешняя среда (индекс ММВБ; индекс РТС; цена на нефть марки

\footnotetext{
${ }^{1}$ Доктор экономических наук, доцент, профессор кафедры «Финансовый менеджмент», Финансовый университет при Правительстве Российской Федерации, Россия, 125993, Москва, ГСП-3, Ленинградский проспект, д. 49; профессор департамента финансов НИУ ВШЭ. E-mail: ecolena@mail.ru.

${ }^{2}$ Доктор технических наук, зав. кафедрой «Прикладная информатика», Финансовый университет при Правительстве Российской Федерации, 125993, Россия, Москва, ГСП-3, Ленинградский проспект, д. 49. E-mail: yuri. zelenkov@gmail.com.

${ }^{3}$ Ведущий экономист, Центральный банк Российской Федерации (Банк России), 107016, Россия, Москва, ул. Неглинная, д. 12, E-mail: chekrizovdv@mail.ru.

${ }^{4}$ Финансовый университет при Правительстве Российской Федерации, 125993, Россия, Москва, ГСП-3, Ленинградский проспект, д. 49; финансовый аналитик, «Фольксваген Груп Рус», 117485 Россия, г. Москва, ул. Обручева, д. 30/1.
} 